Dept. of Vet. Medicine,

Faculty of Vet. Med., Alexandria University,

Head of Dept. Prof. Dr. M.M. El-Shinnawy.

\title{
TUBERCULIN RESPONSE RELATED TO THE ADMINISTRATION OF SOME VIRAL AND BACTERIAL VACCINES \\ (With Two Tables)
}

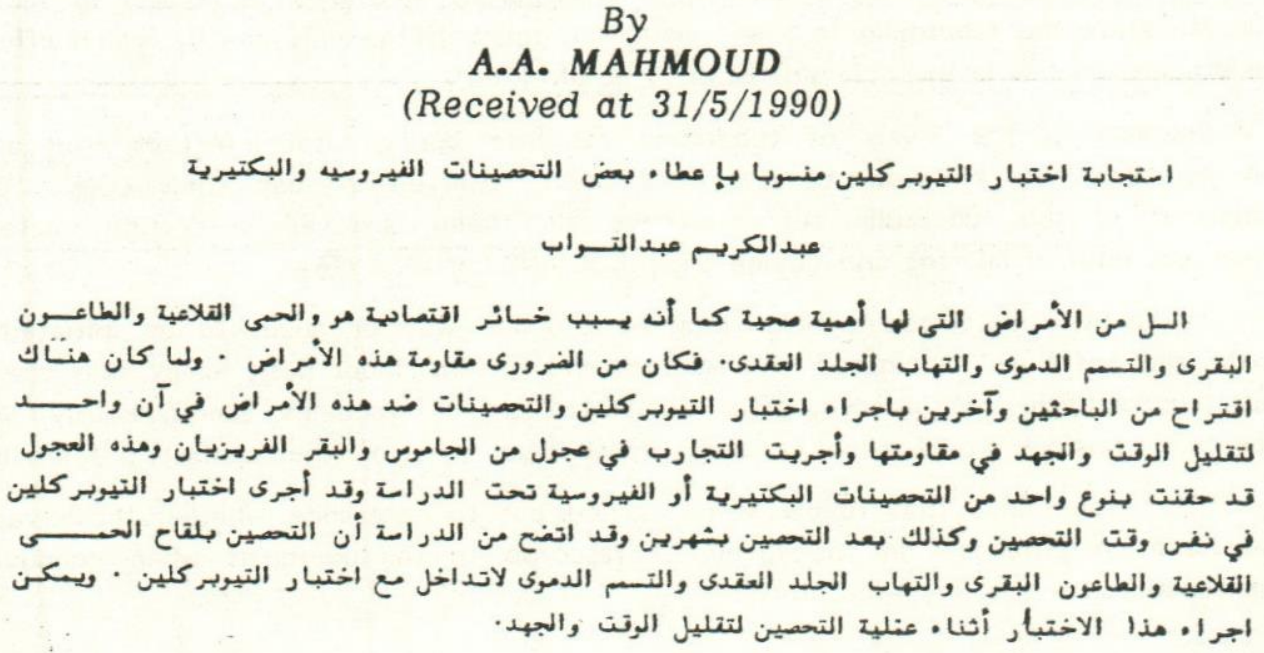

\section{SUMMARY}

The public health importance of tuberculosis and the economic losses caused by the disease and the other's named rinder pest, foot and mouth, lumphy skin disease and haemorrhagic septicaemia make eradication of these diseases are essential.

The suggestion made by the author and others that tuberculin, testing and vaccination programmemeasures should be carried out simultaneously to reduce the time and the cost of the campaign. The experiments were investigated in freizian and buffaloe calves both sensitized with BCG vaccine and six weeks later, each group vaccinated with one viral or bacterial vaccines under the study. Tuberculin testing were carried out simultaneously and two months later of vaccinations.

In conculsion foot and mouth, rinder pest, lumpy. skin and haemorrhagic septicaemia vaccination did not interfer with tuberculin reactions. A fact which may be of economic value during control campaign. 


\section{A.A. MAHMOUD}

\section{INTRODUCTION}

Tuberculosis causes extensive waste and major concern to the cattle industry. The occurrence of the disease, in animals and man adds both economic and public health importance.

The methods used for eradication of tuberculosis depend on a number of factors but ultimately the tuberculin test and slaughter policy is the only one by which effective eradiçation has been achieved (BLOOD, et al. 1986).

A decrease in the levels of tuberculin response during viral infections and after the administration of viral vaccines has been observed in man (BENTZON, 1953). Variations of the tuberculin response have also been observed in certain bacterial infections, both in humans and guinea pigs (COLDING, et al. 1976).

In Egypt, tuberculosis control programme under way or about to be initiated in cattle and buffaloes vaccinated against foot and mouth, rinder pest, lumpy skin disease and haemorrhagic septicaemia. The administration of vaccines simultaneously with tuberculin testing would simplify and reduce the cost of the control programmes.

The experiments that follow were carried out to determine whether those vaccines have an influence on the levels of response to the tuberculin when conducted simultaneously or shortly before this test.

\section{MATERLAL and METHODS}

\section{Experimental animals:}

Hundred thirty freizian calves and ninty buffaloe calves, approximately 6-9 months old with no history of previous vaccination were used. They were clinically healthy and proved to be free from internal and blood parasite as revealed by examination of faecal samples and periferal blood samples stained with Giemsa stain (BODDIE, 1959).

\section{Vaccines:}

a) Monovalent foot and mouth disease (FMD) vaccine type 0, with aluminum

c.. hydroxide and saponin.

b) Attenuated tissue culture rinder pest (RP) vaccine.

c) Attenuated sheep pox vaccine used in cattle to protect them against lumpy skin disease (CAPSTICK and COACKLEY, 1967).

d) Oil adjuvent vaccine of haemorrhagic septicaemia (HS).

Assiut Vet.Med.l Vol. 24, No. 48, January 1991. 


\section{TUBERCULIN VIRAL \& BACTERIAL VACCINES}

The above mentioned vaccines were obtained from Serum and Vaccine Research Institute Abbasia Cairo.

e) BCG

The strain used for human vaccination and produced by Jap, BCG, Lab., Tokyo, Japan, was obtained through the Egyptian organization for Biological and Vaccine Production, Agouza, Cairo.

\section{Tuberculin:}

Mammalian tuberculin was obtained from Serum and Vaccine Research Institute, Abbasia, Cairo.

\section{Experimental design:}

Sensitization of calves: Calves were sensitized by intradermal inoculation of BCG in a dose of 10-20 million organisms.

\section{A - Four experiments were carried out in freizian calves:}

Experiment No. (1):

Twenty sensitized calves vaccinated with FMD vaccine in a dose $5 \mathrm{ml}$ subcutaneously.

Experiment No. (2):

Twenty two sensitized calves, vaccinated with tissue culture RP vaccine in dose of $10^{2} \quad D_{50}$ subcutaneously (the ampoule contain 200 dose dissolved in $200 \mathrm{ml}$ normal saline, each calf received $1 \mathrm{ml}$ ).

Experiment No (3):

Twenty five sensitized calves, vaccinated with sheep pox vaccine (the content of ampoule contain 200 doses dissolved in $100 \mathrm{ml}$ normal saline and each calf received

$1 / 2 \mathrm{ml}$ intradermally in a caudal fold.

Experiment No (4):

Twenty three sensitized calves, vaccinated with oil adjuvent vaccine of $H S$ in a dose of $Z \mathrm{ml}$ intramuscular.

Ten BCG sensitized and non vaccinated calves were used as control group in each experiment.

\section{Single intradermal tuberculin test:}

The method of HERBERT (1974) was applied in tuberculin testing of calves under experiments at time of vaccination and 2 months later. The test was performied in the neck with mammalian tuberculin and the readings of the reactions were made. by measuring the differences in the skin fold thickness before inoculation and 72 hours after. 


\section{A.A. MAHMOUD}

\section{B - Buffaloe calves:}

As in freizian calves similar procedure was carried out.

\section{Experiment No. (1):}

Foot and mouth disease vaccine inoculated in twenty five calves.

\section{Experiment No. (2):}

Tissue culture rinder pest vaccine inoculated in twenty two calves.

\section{Experiment No. (3): .}

Oil adjuvent vaccine of haemorrhagic septicaemia inoculated into twenty two calves.

In each experiment a seven BCG sensitized calves and non-vaccinated served as control group.

\section{RESULTS}

The results obtained from freizian and buffaloe calves are respectively presented in tables 1 and 2 .

Tuberculin reaction showed insignificant increase when carried out simultaneously with FMD or sheep pox vaccinations. Also it did not interfere with the test when conducted two months apart.

There was no difference in the tuberculin response between tissue culture rinder pest (RP) vaccinated freizian and buffaloe calves and the controls. At the same time vaccination with oil adjuvent vaccine of $\mathrm{HS}$ in freizian and buffaloe calves did not interfere with tuberculin testing.

\section{DISCUSSION}

The basis of all tuberculosis eradication schemes in the tuberculin test depends on the policy of slaughtering all positive reactors whether they are open cases or not.

In the present study, it was found that insignificant increase in the reaction of tuberculin testing, were observed when FMD vaccination and the test carried out simulaneously. On the other hand, it seems that vaccination did not apparantly interfere with the test carried out two months apart (tables $1 \& 2$ ). The former result was previously supported by the explanation given by BLACK (1979) who reported that FMD vaccine causes hypersensitivity to the animals. The cause was attributed to the

Assiut Vet.Med.l Vol. 24, No. 48, January 1991. 


\section{TUBERCULIN VIRAL \& BACTERIAL VACCINES}

fact that the vaccine contains alluminum hydroxide and saponin which may irritate the skin. The later findings agree with these of DEKANTOR, et al. (1980).

The application of tissue culture RP vaccine in this study did not interfere with tuberculin test (tables $1 \& 2$ ). This might be attributed to the saftey and immunogencity of the live attenuated tissue culture RP vaccine for cattle and buffaloes (SINGH, et al. 1967 and OSMAN, et al. 1985). Moreover, our results agree with that have been reported by OSMAN, et al. (1987) who concluded that RP vaccine did not affect on tuberculin test.

All over results of the present work carried out under our field environmental conditions showed that the simultaneous applications of tuberculin testing with vaccination of calves with sheep pox vaccine, induce insignificant increase in tuberculin reaction. Moreover, it did not interfere with test when conducted two months apart (table 1) these findings were not in agreement with those reported by BENTZON (1953) who observed a decreased reaction to tuberculin after vaccination with some viral vaccines. This controversy might be due to differences in viral vaccines.

Results obtained in tables ( $1 \& 2$ ) pointed out that no difference in tuberculin response between HS vaccinated calves and controls were noticed.

\section{CONCLUSION}

It may be concluded that foot and mouth disease, rinder pest pox and haemorrhagic septicaemia vaccinations in cattle and buffaloes did not significantly interfere with tuberculin test. A fact which may be of economic value during control campaign.

\section{REFERENCES}

Alhaj, I. (1976): Bovine tuberculosis: a general review with special references to Nigeria. Vol.: 46, No. 11, P. 829-410.

Bentzon, J.W. (1953): Tuberculin response after administration of viral vaccine in man Tubercle, 34, 34-36.

Black, B. (1979): Hypersensitivity in cattle part II. Clinical reactions. Vet. Bull. Vol. 49 , No. 2, P. $77-88$.

Blood, D.C.; Henderson, J.A. and Radostitis, O.M. (1986): Veterinary Medicine. 6th Ed., Bailliere, Tindall, London.

Boddie, C.F. (1959): Diagnostic methods in Veterinary Medicine. 6th Ed. Oliver and Boyd, Edinburgh, London.

Capstick, P.B. and Coackley, W. (1967): Protection of cattle against lumpy skin disease. Trials with a vaccine against Neethling type infection. Res. Vet. Sci., 2: 363-368.

Assiut Vet.Med.l Vol. 24, No. 48, January 1991. 


\section{A.A. MAHMOUD}

Colding, H.; Johansen, K.S. and Weis Bentzon, M. (1976): Tuberculin response after bacterial infection. Acta pathologica et microbiologica Scandinavica sect. 84, 255-259.

Dekantor, L.N.; Marchevsky, N. and Lambardo, R. (1980): Tuberculin response. related to the administrationof foot and mouth disease brucellosis and Rabies vaccines. Brit. Vet. J., 136: 98-100.

Herbert, W.H. (1974): Veterinary immunology Black-well Scientific Pub.

Osman, O.A.; Mouaz, M.A.; Athanasious, S. and Abdel Ghaffar, S. (1985): Comparative study of in vitro and in vivo titration of pooled batchesof tissue culture rinder pest vaccine. Al-Azhar J. Pharm. Sci., 4: 117-132.

Osman, O.A.; Mahmoud, A.A.; Mouaz, M.A. and Athanasious, S. (1987): A preliminary study on vaccination of calves with rinder pest and BCG vaccines. Assiut Vet. Med. J., Vol. 19, No. 37, P. 36-43.

Singh, K.V.; Osman, O.A.; Baz, T.I. and El-Cicy, I.F. (1967): The use of tissue culture rinder pest vaccine for Egyptian cattle and water buffaloes. Cornell Vet. L VII: $3-9$.

Table (1)

Tuberculin responses in Freizian calves sensitized with BCG and inoculated with viral and bacterial vaccines

\begin{tabular}{|c|c|c|c|c|}
\hline \multirow{2}{*}{$\begin{array}{l}\text { No. of } \\
\text { Experiment }\end{array}$} & \multirow{2}{*}{ Inoculum } & \multirow{2}{*}{$\begin{array}{l}\text { No. of } \\
\text { animals }\end{array}$} & \multicolumn{2}{|c|}{$\begin{array}{l}\text { Mean tuberculin } \\
\text { response in min. }\end{array}$} \\
\hline & & & $\begin{array}{l}\text { at time of } \\
\text { vaccination }\end{array}$ & $\begin{array}{l}\text { two mouth } \\
\text { later }\end{array}$ \\
\hline \multirow[t]{2}{*}{1} & Foot and mouth disease vaccine & 20 & $14.8+0.23$ & $12.3+0.22$ \\
\hline & Control & 10 & $11.6+0.26$ & $10.1+0.11$ \\
\hline \multirow[t]{2}{*}{2} & Tissue culture rinder pest vaccine & 22 & $11.6+0.52$ & $13.2+0.17$ \\
\hline & Control & 10 & $10.9 \pm 0.43$ & $13 . \overline{1 \pm 0.15}$ \\
\hline \multirow[t]{2}{*}{3} & Sheep pox vaccine & 25 & $15.1+0.56$ & $11.9+0.18$ \\
\hline & Control & 10 & $10.9+0.22$ & $10.9 \pm 0.12$ \\
\hline \multirow[t]{2}{*}{4} & $\begin{array}{l}\text { Oil adjuvent vaccine of } \\
\text { haemorrhagic septicaemia }\end{array}$ & 23 & $11.2 \pm 0.11$ & $12.6 \pm 0.33$ \\
\hline & Control & 10 & $10.8+0.17$ & $12.1 \pm 0.24$ \\
\hline
\end{tabular}

Mean tuberculine response $=$ difference in skin thickness in m.m before and after treatment. 
TUEERCULIN VIRAL \& BACTERIAL VACCINES

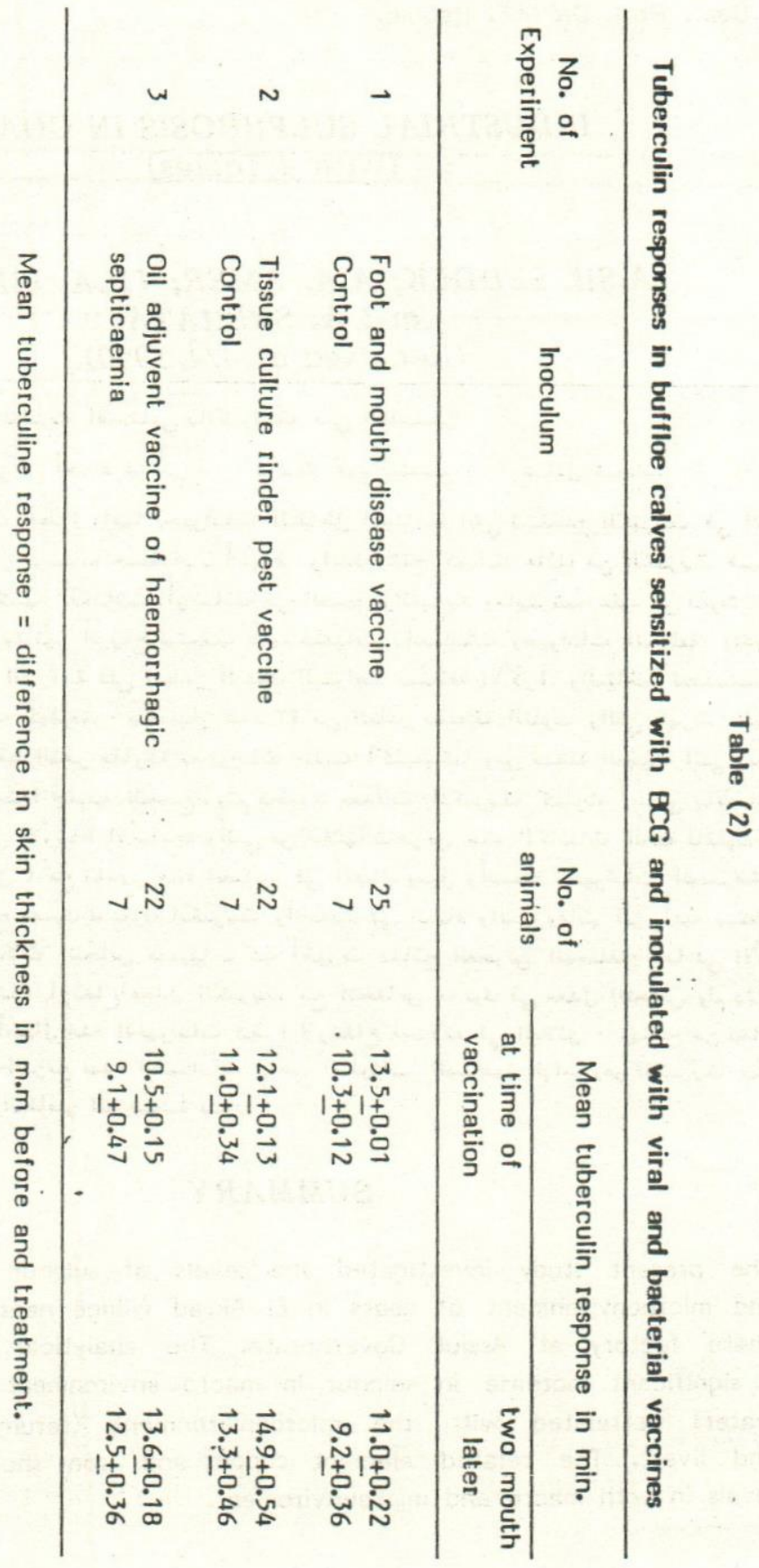

Assiut Vet.Med.J Vol. 24, No. 48, January 1991. 